\title{
Phenolic Contents and Antioxidant Activity of Various Date Palm (Phoenix dactylifera L.) Fruits from Saudi Arabia
}

\author{
Ebtesam Abdullah Saleh $^{1}$, Manal Said Tawfik ${ }^{2,3 *}$, Hamza Mohammed Abu-Tarboush ${ }^{2}$ \\ ${ }^{1}$ National Health Authority, Doha, Qatar; ${ }^{2}$ Food Science and Nutrition Department, Agriculture and Food Science College, King \\ Saud University, Riyadh, Saudi Arabia; ${ }^{3}$ Department of Food Science and Technology, Faculty of Agriculture, Alexandria University, \\ Alexandria, Egypt. \\ Email: *mana92t@yahoo.com
}

Received August $26^{\text {th }}, 2011$; revised October $8^{\text {th }}, 2011$; accepted October $16^{\text {th }}, 2011$.

\begin{abstract}
The present study aimed to estimate the individual and total phenols and antioxidant activity of the aqueous and alcoholic extracts of three premium quality date varieties (Khalas, Sukkari and Ajwa) from Saudi Arabia. In general, water extract has shown significantly higher contents of total phenols than alcoholic, especially in Ajwa (455.88 and 245.66 $\mathrm{mg} / 100 \mathrm{~g}$ respectively). However, phenolic profile indicated that Sukkari contained the highest rutin concentration (8.10 $\mathrm{mg} / \mathrm{kg}$ ), whereas, catechin was approximately the same in Sukkari and Ajwa (7.50 and $7.30 \mathrm{mg} / \mathrm{kg}$ respectively). Khalas was the highest variety content of caffeic acid $(7.40 \mathrm{mg} / \mathrm{kg})$. A significant difference has indicated among extracts and varieties in suppressing lipid peroxidation. Sukkari and Ajwa have reduced the oxidation with $50 \%$ at lower concentration in water extract than alcoholic (0.63, 0.70 and $1.60,1.43 \mathrm{mg} / \mathrm{ml}$ respectively). Furthermore, high positive linear correlation was found between total phenols in water $(r=0.96)$ and alcohol $(r=0.85)$ extracts and inhibition of lipid oxidation activity. The compounds responsible for the activity were catechin $(r=0.96)$, and rutin $(r=0.74)$ in water extract, whereas this correlation decreased in alcoholic extract $(r=0.66)$ for catechin and very weak $(r=0.38)$ for rutin. No correlation was found between caffeic acid and lipid peroxidation in both extracts. Similar significant results were obtained with DPPH test, except with Sukari, which has shown no difference between aqueous and alcoholic extracts $(4.30,4.10 \mathrm{mg} / \mathrm{ml}$ respectively).
\end{abstract}

Keywords: Date Fruit, Total Phenols, Catechin, Rutin, Caffeic Acid, Antioxidant Activity, TBA, DPPH

\section{Introduction}

Fruits and vegetables have been implicated in preventing or reducing the risk of coronary heart diseases [1,2], cancer $[3,4]$ and other chronic diseases [5]. For these reasons, recommendations to increase the dietary intakes of fruits and vegetables have been suggested by many world authorities [6]. Date palm tree, Phoenix dactylifera L., is an important plantation crop for many countries extending from North Africa to the Middle East including many states of the Arabian Gulf Cooperation Countries (GCC).

Date fruits are still considered by many people in this part of the world as a staple food [7].

The potential health benefits of fruits and vegetables have been partially attributed to their polyphenols contents, in particular flavonoids that have received much attention in the literature over the past decade for its biological effects $[8,9]$. Recent studies have reported that palm date fruit (Phoenix dactylifera L.) might be a good source of these active components [10-13]. Also, It was found that palm date has a potent ability to suppress free radicals using different methods $[13,14]$ even within studies that found little contents of total phenols $[11,12]$.

The nutritional and biochemical aspects of date fruits were reported by many workers $[10,13,15-20]$. They are rich in simple sugars such as glucose and fructose $(65 \%$ $80 \%$ ), and a good source of fibers and some essential minerals, but low in fat and protein with no starch [10, 18]. Besides nutritional value, date fruits are rich in phenolic compounds possessing antioxidant activity. Recently, several studies have reported such activity of date fruits from Algeria [12], Kuwait [21], Oman [13] and the 
USA [22].

An antioxidant, which can quench reactive free radicals, can prevent the oxidation of other molecules and may, therefore, have health-promoting effects in the prevention of degenerative diseases [23]. The interest in antioxidants has been increasing because of their high capacity in scavenging free radicals related to various diseases [24].

The antioxidant potentials of Algerian dates have been studied [12]. The total phenolic compounds (TPC) and antiradical efficiency of the Algerian ripe date palm fruits were $2.49-8.36 \mathrm{mg}$ gallic acid equivalents (GAE) per $100 \mathrm{~g}$ fresh weight and $0.08-0.22 \mathrm{mg} / 100 \mathrm{~g}$, respectively. Native sun-dried dates' varieties from Oman have been studied $[13,25]$. The TPC and antioxidant activity (AA) of Omani dates was 172 - 246 mg GAE per $100 \mathrm{~g}$ and $146-162$ 1/mol Trolox equivalents per $\mathrm{g}$ (on a fresh weight basis), respectively [25].

Dates are produced in 35 countries worldwide and cultivated on about 2.9 million acres of land. The world production estimate of date in 2004 was 6,772,068 metric tonnes, and Iran (14\% of world production) is the second major producer after Egypt (17\% of world production) [26].

The aims of this study were to estimate the individual and total phenols in three date varieties, considered to be premium quality and the most consumed in the Kingdom of Saudi Arabia namely Khalas, Sukkari, and Ajwa, their antioxidant activity, and determine the correlation between the antioxidant capacity and phenolic contents.

\section{Materials and Methods}

\subsection{Plant Materials}

Three different ripe date palm (Phoenix dactylifera) fruit varieties known as Khalas, Sukkari and Ajwa were selected in fully ripe stage. Khalas and Sukkari were collected from Riyadh city markets, whereas Ajwa was harvested from Almadina Almonawara city (Saudi Arabia) and stored at $-18^{\circ} \mathrm{C}$.

\subsection{Chemicals}

All chemicals were purchased from Sigma chemical Co., St. Louis, Mo, US. All chemicals and reagents used were of analytical grade.

\subsection{Extraction of the Phenolics}

The phenolics from palm date fruits were extracted as described previously [27]. A portion of $10 \mathrm{~g}$ of date fruit was extracted with $90 \mathrm{ml}$ of water or methanol $(99 \%)$, after being mixed by magnetic stirrer for half an hour, and then filtered with filter paper Whatman No. 41. The remaining materials were re-extracted three times, and then concentrated by lyophilization until dryness.

\subsection{Determination of Total Phenols}

Total phenol content was determined according to the method described by Negi et al. (2003) [28].

\subsection{Determination of Glycosides in Dates}

Sugars were determined in dates according to AOAC method [29] by using HPLC (Shimadzu LC-10 Ad, Kyoto, Japan).

\subsection{Flavonoids and Phenolic Compound Quantification}

The extraction and the separation of flavonoides were done according to Lunn (2000) [30]. The separations of individual phenols in extracts were carried out on Shimadzu liquid chromatographic system. For rutin extraction $2 \mathrm{~g}$ of date sample was homogenized in $100 \mathrm{ml}$ of mixture of water-methanol-acetic acid (55:40:5) and for caffeic acid date sample was homogenized in $100 \mathrm{ml}$ of mixture of water-methanol (50:50). For catechin extraction $5 \mathrm{~g}$ of date sample was homogenized in $50 \mathrm{ml}$ of phosphoric acid. The extract was put in a sonomatic Langford (Model $575 \mathrm{H}$ ) at temperature $60^{\circ} \mathrm{C}$ around 15 min for rutin and caffeic acid, around $60 \mathrm{~min}$ for catchin. The mixture was filtered and concentrated by a rotary evaporator (BiBBy, Model RF 200 B) to 10 ul. A 20 ul aliquot of this solution was injected into the HPLC system (Shimadzu, Japan) using a Shim-Pack CLC-ODS column with flow rate $1 \mathrm{ml} / \mathrm{min}$. The mobile phase was water-methanol-acetic acid (50:50:1, v/v). The wavelengths used were $254 \mathrm{~nm}$ for rutin, $274 \mathrm{~nm}$ for caffeic acid and $555 \mathrm{~nm}$ for catechin. The chromatographic peaks of the phenols were confirmed by comparing their retention times and UV spectra with that of their reference standards.

\subsection{Thiobarbituric Acid Reactive Substances (TBARS)}

Assessment of lipid oxidation was achieved by evaluation the formation of TBARS according to the method of Garcia-Alonso et al. [31] with some modification. The reagents were added in the following order: $230 \mu \mathrm{KCl}$ $(150 \mathrm{mM})$, date extracts $(40 \mu \mathrm{l})$ of different concentrations, control (1) was without test sample, and phosphatidylcholine $(1 \mathrm{mg} / \mathrm{ml})$. Lipid peroxidation was induced by adding $40 \mu \mathrm{FeCl}_{3}(20 \mathrm{mM})$ plus $40 \mu \mathrm{l}$ ascorbate $(50 \mathrm{mM})$. To eliminate the possible interference of TBA with sugars, control (2) was made up by adding all reagents without oxidized substrates. After incubation at $37^{\circ} \mathrm{C}$ for $60 \mathrm{~min}$, the reaction was stopped by adding 0.8 $\mathrm{ml}$ of $20 \%$ trichloroacetic acid (TCA) $/ 0.4 \%$ thiobarbi- 
turic acid (TBA) $/ 0.25 \mathrm{~N} \mathrm{HCl}$, and $0.01 \mathrm{ml}$ of BHT, and the reaction mixture was boiled for $15 \mathrm{~min}$, then cooled, centrifuged and absorbance of the supernatant was measured at $532 \mathrm{~nm}$ after using control (2) to zero in the spectrophotometer. The ability of the extract to inhibit the peroxidation was calculated using the following equation:

Peroxidation inhibition $(\%)=\left(\right.$ Control $_{1}$ OD

- sample OD/Control 1 OD) $\times 100$.

\subsection{Free Radical Scavenging Capacity}

Antioxidant activity was determined by the 2,2,diphenyl2-picryl-hydrazyl (DPPH) method [12,32]. A portion of $1.950 \mathrm{ml}$ of DPPH solution $\left(6 \times 10^{-5} \mathrm{M}\right)$ diluted in methanol was incubated with $50 \mu \mathrm{l}$ of the extract, of varying concentrations. The absorbance of the mixture was measured at $515 \mathrm{~nm}$, and radical scavenging activity was expressed as the efficient concentration $\left(\mathrm{EC}_{50}\right)$ which represent the amount of antioxidant necessary to decrease the initial DPPH concentration by $50 \%$.

\subsection{Statistical Analysis}

Turkey test was used in showing the statistical significance between different samples. The different is significant at $P \leq 0.05$. Data were analyzed using SPSS.

\section{Results and Discussion}

\subsection{Total Phenols and Glycosides in Dates}

Table 1 shows that the concentration of total polyphenols depends on date variety and extraction solvent. Total polyphenols in Ajaw water extract $(455.88 \mathrm{mg} / 100 \mathrm{~g})$ was the highest compared to sukkari $377.66 \mathrm{mg} / 100 \mathrm{~g}$ and khalas $238.54 \mathrm{mg} / 100 \mathrm{~g}$ extracts $(P \leq 0.05)$ Total polyphenols in alcohol extract of the three date varieties followed the same trend as in water extract. However, polyphenols in the water extract was higher significantly compared to the alcohol extract $(P \leq 0.05)$.

The concentration of polyphenols in this study was

Table 1. Total phenols contents (TP) of water and alcohol extracts in different date varieties.

\begin{tabular}{|c|c|c|}
\hline \multirow{2}{*}{ Solvents Varieties } & \multicolumn{2}{|c|}{$\mathrm{TP}^{*}(\mathrm{mg} / 100 \mathrm{~g})$} \\
\hline & Water & Alcohol \\
\hline Ajwa & $455.88 \pm 6.9_{\mathrm{a}}^{\mathrm{A}}$ & $245.66 \pm 4.5_{\mathrm{b}}^{\mathrm{A}}$ \\
\hline Sukari & $377.66 \pm 6.4_{\mathrm{a}}^{\mathrm{B}}$ & $222.7 \pm 5.3_{\mathrm{b}}^{\mathrm{B}}$ \\
\hline Khalas & $238.54 \pm 10_{\mathrm{a}}^{\mathrm{C}}$ & $106.06 \pm 7.3_{\mathrm{b}}^{\mathrm{C}}$ \\
\hline
\end{tabular}

Means \pm SD of triplicate. Values with different superscripts in the same column are significantly different $(P \leq 0.05)$. Values with different subscripts in the same row are significantly different $(P \leq 0.05)$. TP ${ }^{*}$ : Total Phenols. lower compared to study of Sawaya et al. 1983 [10] for the same varieties. This could be due to the difference of the method that is used which involved boiling the sample. Moreover, soil and climatic differences could have affect polyphenols content in dates.

It was found also that the dark variety of date (Ajwa) had the highest concentration of polyphenols, whereas the light variety (Khalas) contained the lowest (Table 1). This finding agreed with the study of Beretta et al. [33] who found a high correlation $(r=0.93)$ between polyphenols concentration and the color of honey. However, Al-Farsi et al. [13] found negative correlation between polyphenols and the color of dates. This could be due to stage of date as they studied the ratab stage of date that differs from tamar (fully ripe) stage, which was used in this investigation.

Our results are in agreement, to some extent, with that reported by Al-Farsi et al., [13] who found that total phenol contents of dates were 308 and $276 \mathrm{mg} / 100 \mathrm{~g}$ in methanol and water extracts respectively. On the other hand, in studies carried out by Wu et al., [11] and Mansouri et al. [12], date (Deglet Noor variety) has being showed much lower concentration in total phenols as compared to the present study. This variation could be explained by the absence of monomer and polymer of proanthocyanin of that variety [34] as well as its lower content of phenolic acids [35].

The concentration of total polyphenols in this study determined by Folin-ciocaltue method, which is, could be affected by protein, ascorbic acid and reducing sugars especially fructose [36,37]. Therefore, concentration of sugars was determined in this study (Figure 1). The concentrations of glucose and fructose were the higher in Ajwa and Khalas compared to Sukkari, whereas total polyphenols concentration was the highest in Ajwa and Sukkari and the lowest in Khalas accordingly sugars in dates could had no interference with Folin-Ciocaltue test. Gheldof and Engeseth [36] found effect of sugars in Folin-cicoltue test for different fruits.

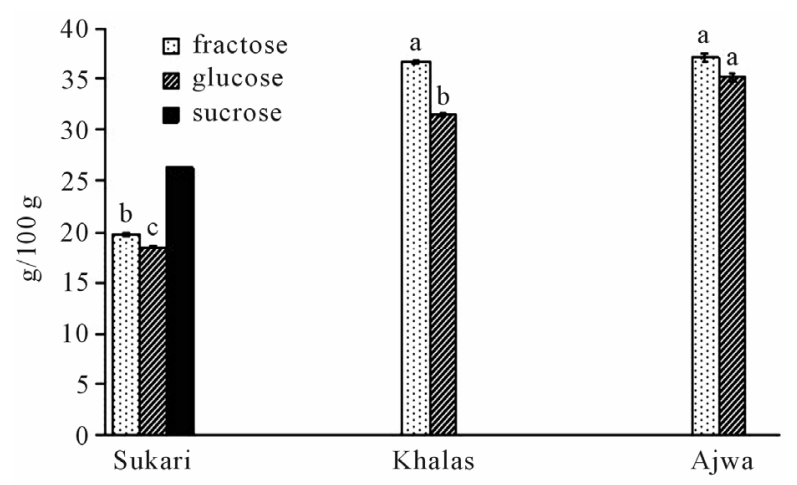

Figure 1. Glycosides determination in date samples. 


\subsection{Flavonoides and Phenolic Compounds}

The protective role of flavonoids, specifically flavanols and flavonols, from cardiovascular and cancer diseases has pointed out $[8,9,38]$. Therefore, in this study catechin, rutin and nonflavonoid (caffeic acid) were determined of three varieties of date by HPLC analysis. As seen in Table 2 content of rutin in Sukkari $(8.10 \mathrm{mg} / \mathrm{kg})$ was significantly higher than in Ajwa and Khalas (6.50 and 3.60 $\mathrm{mg} / \mathrm{kg}$ respectively). However, the content of catechin in Sukkari and Ajwa was significantly equal (7.50 and 7.30 $\mathrm{mg} / \mathrm{kg}$ ), whereas in Khalas was significantly lower than latter varieties $(5 \mathrm{mg} / \mathrm{kg})$. On the other hand, there was no significant difference of the content of caffeic acid between Ajwa and Sukhri where it was higher in khalas (Table 2). In other varieties caffeic acid is almost close to our result [36] However, it was so much lower than Al-farsi, [13] finding $(76 \mathrm{mg} / \mathrm{kg})$. This could be due to the difference of varieties and applied determining method.

\subsection{Antioxidant Activities}

\subsubsection{Inhibition of Lipid Peroxidation}

Since the absence of one test that provides all information about antioxidants activity in the natural materials extracts, there is a pressing need for using different methods to evaluate the effective activity of a studied sample towards the free radicals, and though, achieving an accurate measurement for the antioxidant activity [39, 40]. Thus, the combination of two assays, TBARS and $\mathrm{DPPH}$, were applied in this study.
It is observed from Table 3 that the required concentration for reducing $50 \%$ of lipid peroxidation was significant $(P<0.05)$ less in Ajwa and Sukkari $(0.70,0.63$ and 1.43 and $1.60 \mathrm{mg} / \mathrm{ml})$ than in Khalas $(0.96$ and 1.88 $\mathrm{mg} / \mathrm{ml}$ ) in both aqueous and alcoholic extracts respectively. Moreover, the difference between the solvents to inhibit $50 \%$ of lipid peroxidation has also been significant $(P<0.05)$, as the aqueous extract of Ajwa and Sukkari reached more than $50 \%$ of its concentration in alcoholic solvent and about half for Khalas. This finding confirms Al-Farsi et al., [13] suggestion that most of the antioxidants types in dates are hydrophilic. Although the most antioxidants in date fruit are water-soluble, it has shown a potent ability to act as antioxidant activity in lipids membranes system. This is could be partially due to the property of flavanols which can react in both side of water and lipid layers of cell membranes [21,41], and therefore protecting from oxidative degradation. Vayalill [21], measured antioxidant acitivity of tamer by the same test (TBA). He found that reduction $50 \%$ of lipids peroxidation requires $(1.9 \mathrm{mg} / \mathrm{ml})$ of date water extract. This concentration is much higher compared to those found in this study, although the stage of date in his study was fresh (rutab), which is supposed to reflect greater activity than tamer stage $[13,42]$. A possible explanation of this difference could be attributed the time that the extraction was added in his experiment, was after incubation, and this may allow more generation of free radicals, and therefore the concentration of extract was needed to be rise. Also it may be referred to the variety.

Table 2. Individual phenols analyzed by HPLC (mg/kg).

\begin{tabular}{cccc}
\hline \multirow{2}{*}{ Phenol type } & \multicolumn{3}{c}{ Date Varieties } \\
\cline { 2 - 4 } & Ajwa & Sukhari & Khalas \\
\hline Rutin & $6.50 \pm 1.70^{\mathrm{a}}$ & $8.10 \pm 0.20^{\mathrm{b}}$ & $3.60 \pm 0.07^{\mathrm{c}}$ \\
Catechin & $7.30 \pm 0.14^{\mathrm{a}}$ & $7.50 \pm 0.70^{\mathrm{a}}$ & $5.00 \pm 0.18^{\mathrm{b}}$ \\
Caffeic acid & $5.70 \pm 0.77^{\mathrm{a}}$ & $5.40 \pm 0.64^{\mathrm{a}}$ & $7.40 \pm 1.61^{\mathrm{b}}$ \\
\hline
\end{tabular}

Means \pm SD of duplicate. Values with different superscripts in the same row are significantly different $(P \leq 0.05)$.

Table 3. Total antioxidant activity and capacity (TBA and DPPH assays) of water and alcohol extracts in different date varieties.

\begin{tabular}{|c|c|c|c|c|}
\hline \multirow{2}{*}{ Solvents Varieties } & \multicolumn{2}{|c|}{$\mathrm{TBA}^{*}(\mathrm{mg} / \mathrm{ml})$} & \multicolumn{2}{|c|}{$\mathrm{DPPH}^{* *}(\mathrm{mg} / \mathrm{ml})$} \\
\hline & Water & Alcohol & Water & Alcohol \\
\hline Sukari & $0.63 \pm 0.04_{\mathrm{a}}^{\mathrm{A}}$ & $1.60 \pm 0.08_{\mathrm{b}}^{\mathrm{A}}$ & $4.30 \pm 0.04_{a}^{\mathrm{B}}$ & $4.10 \pm 0.14_{\mathrm{a}}^{\mathrm{A}}$ \\
\hline
\end{tabular}

Means \pm SD of triplicate. Values with different superscripts in the same column are significantly different $(P \leq 0.05)$. Values with different subscripts in the same row for each assay are significantly different $(P \leq 0.05)$. TBA*: Thiobarbituric acid; DPPH ${ }^{* *}:$ diphenylpicrylhydroic. 
Correlation between the content of either total or individual phenols and antioxidant capacity was calculated in this study. It was found high positive linear correlation with total phenols $\left(r^{2}=0.96, r^{2}=0.85\right)$ in water and alcohol extracts respectively, and with catechin and rutin $\left(r^{2}=0.94, r^{2}=0.74\right)$ in aqueous extract. However, this correlation with catechin and rutin in alcohol extract decreased to $\left(r^{2}=0.66\right)$ and $\left(r^{2}=0.38\right)$ respectively. Regarding to caffeic acid, it was found a negative correlation with the antioxidant activity. These data indicate that the antioxidant activity was obtained directly from phenolics, particularly catechin and rutin, and assures other experiments that mentioned the same vital role of catechin and rutin in lipid peroxidation inhibition [41,43,44]. $\mathrm{Wu}$ et al. [11] has reported a strong linear relationship between antioxidant activity using ORAC assay, and total phenols of Deglet Noor Varity. However, in other work [13] even though using the same assay, this correlation was not found. The difference in this correlation between our outcomes and Al-Farsi [13] may attribute to the properties of phenolics that may react well in certain assay and decrease in another one as Garcia-Alonso et al. citied [31]. Furthermore, some date varieties do not contain monomer or polymer of proanthocyain [35], which show high contribution to the antioxidant capacity in this study and in others [40,44], and therefore Fard and khasab varieties that used in Al-Farsi et al., study [13] may not contain these active components.

\subsubsection{Free Radical Scavenging Capacity}

The $\mathrm{EC}_{50}$ values determined by DPPA assay of the samples tested offered significantly $(P<0.05)$ the same reactivity order as shown with polyphenols: Ajwa $>$ Sukkari $>$ Khalas $(2.90,4.30,6.60 \mathrm{mg} / \mathrm{ml})$, Ajwa $=$ Sukkari $>$ Khalas $(3.80,4.10$ and $9.10 \mathrm{mg} / \mathrm{ml})$ in water and alcohol respectively (Table 3 ). Also between the solvents: water $>$ alcohol, the lower the $\mathrm{EC}_{50}$, the higher the antioxidant capacity. However, ANOVA analysis showed that there is no significant different among extracts in Sukkari variety. These data assures of the antioxidant water-soluble type that date fruit contains.

Since, Ajwa has shown the highest antioxidant activity among other varieties, the kinetic behavior of Ajwa extracts (aqueous and alcohol) were estimated at different concentrations in both aqueous and alcohol extracts (Figure 2). The steady state was reached in less than $2 \mathrm{~h}$ compared to alcoholic extract which reacted very more slowly with DPPH taking $20 \mathrm{~h}$ to reach a steady state. Mansouri et al. [12] reported that a DPPH radical scavenging activity of date fruit was associated with the contents of the total phenolics $\left(r^{2}=0.99\right)$.

This implies that Ajwa, which shows strongest antioxidant capacity rather than other varieties, in particular

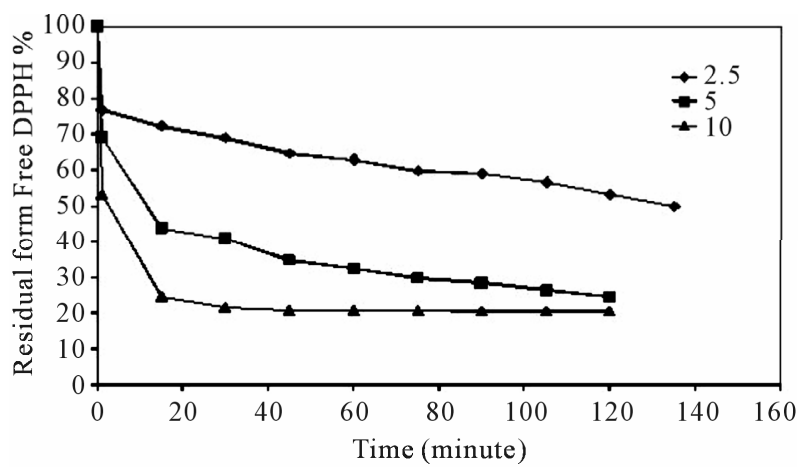

(a)

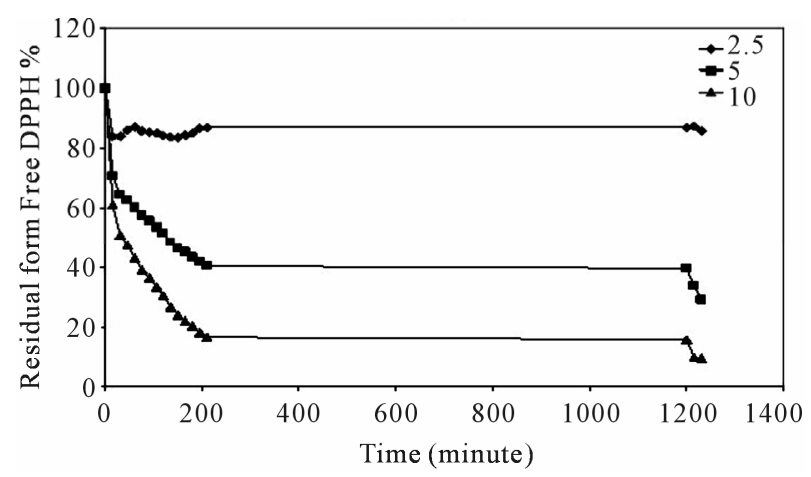

(b)

Figure 2. The kinetic behavior of free radical scavenging capacity of Ajwa in (a) aqueous and (b) alcohol extracts at different concentrations.

in water extract, may contain other unmeasured potent polyphenolic antioxidant, in particular proanthocyaindins. These biocomponents, the polymer of catechins, which have been found in some date varieties [27,45] may make a large contribution to this activity.

A consideration can be drafted from the comparison of data obtained with different antioxidant methods. It appears that the ability of date extract to prevent the generation of free radicals through iron chelating was the major antioxidant mechanism responsible for the observed antioxidant activity. This interpretation is supported by Guo et al. [14], who found that date fruit has the second antioxidant activity among 28 fruits by using FRAP test. Ferrous $\left(\mathrm{Fe}^{2+}\right)$ is capable of generating free radicals from peroxides by the Fenton reaction and is implicated in many diseases [45], and reduction of $\mathrm{Fe}^{2+}$ concentrations in the Fenton reaction would protect against oxidative damage. Nevertheless, Vayalil [21] assumed different mechanism of date extract by suppressing hydroxyl-radical, according to hydroxyl radical assay that give same concentration to reduce the complete inhibition as TBA test does $(4.0 \mathrm{mg} / \mathrm{ml})$. However, it should be taken into consideration that both assays which were used in the experiment contain same free 
radical generator, iron, and therefore, concluding with the latter postulation, in some extent, is difficult to be assured.

\section{Conclusions}

The presented data in this study confirms that date fruit can be considered a rich source of hydrophilic antioxidant, and this reducing property is generally associated with the presence of polyphenols specifically flavanols.

\section{Acknowledgements}

This research project was supported by a grant from the research center of the center for female scientific and medical colleges in King Saud University.

\section{REFERENCES}

[1] E. B. Rimm, A. Ascherio, E. Giovannucci, D. Spiegelman, M. J. Stampfer and W. C. Willett, "Vegetable, Fruit, and Cereal Fiber Intake and Risk of Coronary Heart Disease among Men," Journal of American Medical Association, Vol. 275, No. 6, 1996, pp. 447-451. doi:10.1001/jama.1996.03530300031036

[2] R. Blomhoff, "Dietary Antioxidants and Cardiovascular Disease," Current Opinion in Lipidology, Vol. 16, No. 1, 2005, pp. 47-54. doi:10.1097/00041433-200502000-00009

[3] G. Block, B. Patterson and A. Subar, "A Fruit, Vegetables, and Cancer Prevention: A Review of the Epidemiological Evidence," Nutrition and Cancer, Vol. 18, No. 1, 1992, pp. 1-29. doi:10.1080/01635589209514201

[4] M. S. Donaldson, "Nutrition and Cancer Diet: A Review of the Evidence for an Anti-Cancer Diet," Nutrition Journal, Vol. 3, No. 20, 2004, pp. 19-40. doi:10.1186/1475-2891-3-19

[5] D. A. Cooper, "Carotenoids in Health and Disease: Recent Scientific Evaluations, Research Recommendations and the Consumer," The Journal of Nutrition, Vol. 134, No. 1, 2004, pp. 221S-224S.

[6] World Health Organization and Food and Agriculture Organization (WHO/FAO), "A Report of Joint WHO/ FAO Expert Consultation on Diet, Nutrition and the Prevention of Chronic Diseases," Technical Report Series No. 916, Geneva, 2003.

[7] W. Erskine, T. Moustafa and A. E. Osman, "Date Palm in the GCC Countries of the Arabian Peninsula," 2006. http://www.icarda.org/APRP/Datepalm/introductio/introbody.htm

[8] M. G. L. Hertog, E. J. M. Feskens, P. C. H. Hollman, M. B. Katan and D. Kromhout, "Dietary Antioxidant Flavonoids and Risk of Coronary Heart Disease the Zutphen Elderly Study," Lancet, Vol. 342, No. 8878, 1993, pp. 1007-1011. doi:10.1016/0140-6736(93)92876-U

[9] M. G. L. Hertog, D. Kromhout, C. Aravanis, H. Blackburn, R. Buzina, F. Fidanza, S. Giampaoli, A. Jansen, A. Menotti, S. Nedeljkovic, M. Pekkarinen, B. S. Simic, H.
Toshima, E. J. M. Feskens, P. C. H. Hollman and M. B. Katan, "Flavonoid Intake and Long-Term Risk of Coronary Heart Disease and Cancer in the Seven Countries Study," Archive International Medicine, Vol. 155, No. 5, 1995, pp. 381-386. doi:10.1001/archinte.1995.00430040053006

[10] W. N. Sawaya, W. M. Safi, L. T. Black, A. S. Mashadi and M. M. Al-Muhammad, "Physical and Chemical Characterization of the Major Date Varieties Grown in Saudi Arabia II. Sugars, Tannins, Vitamins A and C," Date Palm Journal, Vol. 2, No. 2, 1983, pp. 183-196.

[11] X. Wu, G. R. Beecher, J. M. Holden, D. B. Haytowttz, S. E. Gebharadt and R. L. Prior, "Lipophilic and Hydrophilic Antioxidant Capacities of Common Foods in the United States," Journal of Agriculture and Food Chemistry, Vol. 52, No. 12, 2004, pp. 4026-4037. doi:10.1021/jf049696w

[12] A. Mansouri, G. Embarek, E. Kokkalou and P. Kefalas, "Phenolic Profile and Antioxidant Activity of the Algerian Ripe Date Palm Fruit (Phoenix dactylifera)," Food Chemistry, Vol. 89, No. 3, 2005, pp. 411-420. doi:10.1016/j.foodchem.2004.02.051

[13] M. Al-Farsi, C. Alasalvar, A. Morris, M. Baron and F. Shahidi, "Comparison of Antioxidant Activity, Anthocyanins, Carotenoids, and Phenolics of Three Native Fresh and Sun-Dried Date (Phoenix dactylifera L.) Varieties Grown in Oman," Journal of Agriculture and Food Chemistry, Vol. 53, No. 11, 2005, pp. 7592-7599. doi:10.1021/jf050579q

[14] C. Guo, J. Yang, J. Wei, Y. Li, J. Xu and Y. Jiang, “Antioxidant Activities of Peel, Pulp and Seed Fractions of Common Fruits as Determined by FRAP Assay," Nutrition Research, Vol. 23, No. 12, 2003, pp. 1719-1726. doi:10.1016/j.nutres.2003.08.005

[15] M. J. Abdel Hafiz, A. F. Shalabi and S. Y. Risk, "Chemical Composition of 15 Varieties of Dates Grown in Saudi Arabia," Proceedings of Saudi Biological Society, Vol. 4, No. 2, 1980, pp. 180-194.

[16] W. H. Barreveld, "Date Palm Products," Bulletin No. 101, Food and Agriculture Organization of the United Nations, Rome, 1993.

[17] I. Booij, G. Piombo, J. M. Risterucci, M. Coupe, D. Thomas and M. Ferry, "Study of Chemical Composition of Dates at Different Stages of Maturity for Varietals Characterization of Different Cultivars of Dates," Fruit-Paris, Vol. 47, No. 6, 1992, pp. 667-678.

[18] R. M. Myhara, J. Karkalas and M. S. Taylor, "The Composition of Maturing Omani Dates," Journal of the Science of Food and Agriculture, Vol. 79, No. 11, 1999, pp. 1345-1350. doi:10.1002/(SICI)1097-0010(199908)79:11<1345::AIDJSFA366>3.0.CO;2-V

[19] W. N. Sawaya, H. A. Khatchadourian, J. K. Khalil, W. M. Safi and A. Al-shalhat, "Growth and Compositional Changes during the Various Developmental Stages of Some Saudi Arabian Date Cultivars," Journal of Food Science, Vol. 47, No. 5, 1982, pp. 1489-1492. doi:10.1111/j.1365-2621.1982.tb04967.x 
[20] G. F. Sourial, A. S. Khalifa, S. I. Gaafar, A. A. Tewfik and I. A. Mousa, "Evaluation of Some Selected Date Cultivars Grown in Sharkiya Vine. Egypt. 2. Chemical Composition," Proceeding of the Second Symposium of the Date Palm in Saudi Arabia, Al-Ahsa, 1986, pp. 141-152.

[21] P. K. Vayalil, "Antioxidant and Antimutagenic Properties of Aqueous Extract of Date Fruit (Phoenix dactylifera L. Arecaceae)," Journal of Agricultural and Food Chemistry, Vol. 50, No. 3, 2002, pp. 610-617. doi:10.1021/jf010716t

[22] J. A. Vinson, L. Zubic, P. Bose, N. Samman and J. Proch, "Dried Fruits: Excellent in Vitro and in Vivo Antioxidants," Journal of the American College of Nutrition, Vol. 24, No. 1, 2005, pp. 44-50.

[23] F. Shahidi, "Natural Antioxidants Chemistry, Health Effects, and Applications," AOCS Press, Urbana, 1997.

[24] E. M. Silva, J. N. S. Souza, H. Rogez, J. F. Rees and Y. Larondelle, "Antioxidant Activities and Polyphenolic Contents of Fifteen Selected Plant Species from the Amazonian Region," Food Chemistry, Vol. 101, No. 3, 2007, pp. 1012-1018. doi:10.1016/i.foodchem.2006.02.055

[25] M. Al-Farsi, C. Alasalvar, M. Al-Abid, K. Al-Shoaily, M. Al-Army and F. Al-Rawahy, "Compositional and Functional Characteristics of Dates, Syrups and Their ByProducts," Food Chemistry, Vol. 104, No. 3, 2007, pp. 943-947. doi:10.1016/i.foodchem.2006.12.051

[26] FAO Date Palm Production Chapters 1 \& 2, 2004. http:www.FAO.org on 2007/05/24

[27] R. P. Singh, C. K. N. Murthy and G. K. Jayaprakasha, "Studies on the Antioxidant Activity of Pomegranate (Punica granatum) Peel and Seed Extracts Using in Vitro Models," Journal of Agricultural and Food Chemistry, Vol. 50, No. 1, 2002, pp. 81-86. doi:10.1021/jf010865b

[28] P. S. Negi, G. K. Jayaprakasha and B. S. Jena, "Antioxidant and Antimutagenic Activities of Pomegranate Peel Extracts," Food Chemistry, Vol. 80, No. 3, 2003, pp. 393397. doi:10.1016/S0308-8146(02)00279-0

[29] Association of Official Analytical Chemists (AOAC), "Official Methods of Analysis," 16th Edition, AOAC International, Washington DC, 1995.

[30] G. Lunn, "HPLC Methods for Pharmaceutical Analysis," Interscience Publication, New York, 2000.

[31] M. Garcia-Alonso, S. de Pascual-Teresa, C. SantosBuelga and J. C. Rivas-Gonzalo, "Evaluation of the Antioxidant Properties of Fruits," Food Chemistry, Vol. 84, No. 1, 2004, pp. 13-18. doi:10.1016/S0308-8146(03)00160-2

[32] W. Brand-Williams, M. E. Cuvelier and C. Berset, "Use of a Free Radical Method to Evaluate Antioxidant Activity," Lebensmittel-Wissenchaft und-Technologie, Vol. 30, No. 1-3, 1994, pp. 609-615.

[33] G. Beretta, P. Granata, M. Ferrero, M. Orioli and R. M. Facino, "Standardization of Antioxidant Properties of Honey by a Combination of Spectrophotometric/Fluorimetric Assays and Chemometrics," Analytica Chimica Acta, Vol. 533, No. 2, 2005, pp. 185-191. doi:10.1016/j.aca.2004.11.010

[34] C. Regnault-Roger, R. Hadidane, J. F. Biard and K. Boukef, "High Performance Liquid and Thin-Layer Chromatography Determination of Phenolic Acids in Palm (Phoenix dacylifera)," Food Chemistry, Vol. 25, No. 1, 1987, pp. 61-71. doi:10.1016/0308-8146(87)90054-9

[35] V. L. Singleton, R. Orthofer and R. M. Lamuela-Raventos, "Analysis of Total Phenols and Other Oxidation Substrates and Antioxidants by Means of Folin-Ciocalteu Reagent," Methods in Enzymology, Vol. 299, 1999, pp. 152-178. doi:10.1016/S0076-6879(99)99017-1

[36] A. Scalbert and G. Williamson, "Dietary Intake and Bioavailability of Polyphenols," Journal of Nutrition, Vol. 130, No. 8, 2000, pp. 2073S-2085S.

[37] N. Gheldof and N. J. Engeseth, "Antioxidant Capacity of Honeys from Various Floral Sources Based on the Determination of Oxygen Radical Absorbance Capacity and Inhibition of in Vitro Lipoprotein Oxidation in Human Serum Samples," Journal of Agriculture and Food Chemistry, Vol. 50, No. 10, 2002, pp. 3050-3055. doi:10.1021/jf0114637

[38] N. M. A. Hassimotto, M. I. Genovese and F. M. Lajolo, "Antioxidant Activity of Dietary Fruits, Vegetables, and Commercial Frozen Fruits Pulps," Journal of Agriculture and Food Chemistry, Vol. 53, No. 8, 2005, pp. 29282935. doi:10.1021/jf047894h

[39] R. Tsao, R. Yang, S. Xie, E. Scokovie and S. Khanizadeh, "Which Polyphenolic Compounds Contribute to the Total Antioxidant Activities of Apple?" Journal of Agriculture and Food Chemistry, Vol. 53, No. 12, 2005, pp. 49894995. doi:10.1021/jf048289h

[40] N. Caturla, E. Vera-Samper, J. Villalaín, C. R. Mateo and V. Micol, "The Relationship between the Antioxidant and the Antibacterial Properties of Galloylated Catechins and the Structure of Phospholipid Model Membranes," Free Radical Biology and Medicine, Vol. 34, No. 6, 2003, pp. 648-662. doi:10.1016/S0891-5849(02)01366-7

[41] S. V. Verstraeten, C. L. Keen, H. H. Schmitz, C. E. G. Fraga and P. I. Oteiza, "Flavan-3-Ols and Procyanidins Protect Liposomes against Lipid Oxidation and Disruption of the Bilayer Structure," Free Radical Biology and Medicine, Vol. 34, No. 1, 2003, pp. 84-92. doi:10.1016/S0891-5849(02)01185-1

[42] I. B. Afanas'ev, A. I. Dcrozhko, A. V. Brodskii, V. A. Kostyuk and A. I. Potapovitch, "Chelating and Free Radical Scavenging Mechanisms of Inhibitory Action of Rutin and Quercetin in Lipid Peroxidation," Biochemical Pharmacology, Vol. 38, No. 11, 1989, pp. 1763-1769. doi:10.1016/0006-2952(89)90410-3

[43] S. B. Lotito and B. Fre, "Relevance of Apple Polyphenols as Antioxidants in Human Plasma: Contrasting in Vitro and in Vivo Effects," Free Radical Biology and Medicine, Vol. 36, No. 2, 2004, pp. 201-211.

[44] M. R. Al-Obid, "Date Skin as a Source of Antioxidant Activity and Free Radical Scavenging," First International Meeting of Date Palm Phoenix dactylifera L., Qas- 
sim, 2003, pp. 643-658.

[45] B. Halliwell and J. M. C. Gutteridge, "Role of Free Radicals and Catalytic Metal Ions in Human Disease: An
Overview," Methods in Enzymology, Vol. 186, 1990, pp. 1-85. doi:10.1016/0076-6879(90)86093-B 